\title{
Rare disease
}

\section{Congenital epulis}

\author{
Vlasta Merglová, ${ }^{1}$ Petr Mukensnabl, ${ }^{2}$ Pavel Andrle ${ }^{1}$ \\ 'Dentistry Department, Medical Faculty, Charles University in Prague, Pilsen, Czech Republic; \\ 2Pathology Department, Faculty Hospital, Pilsen, Czech Republic
}

Correspondence to Professor Vlasta Merglová, merglovav@fnplzen.cz

\section{Summary}

Congenital epulis is a rare, soft-tissue benign condition that presents at birth. It arises from the alveolar mucosa and occurs more frequently in the maxilla, mainly in the frontal region. This condition may interfere with respiration, feeding or lip closure. Surgical excision is the only possible treatment, although spontaneous regression has been reported. This article presents the case of a female infant with a solid ovoid mass protruding from the oral cavity. Treatment of this lesion was surgical, and histopathological examination confirmed the clinical diagnosis of congenital epulis. Postsurgical follow-up was without complications; examination of the infant 5 months later has revealed only mild left frontal alveolar ridge hypoplasia without any sign of recurrence.
\end{abstract}

\section{BACKGROUND}

The term epulis is used to describe a wide variety of benign tumours and tumour-like conditions in children and adults, regardless of their pathological origin. ${ }^{1-3}$ Congenital epulis is also known as granular cell tumour or myoblastic myoma, which is a rare benign intraoral condition present at birth. The first case was described by Neumann in 1871; hence, it is also known as Neumann's tumour.

The aetiology of congenital epulis is unknown, but many theories have been proposed in an attempt to explain the histogenesis of the tumour, including myoblastic, odontogenic, neurogenic, fibroblastic, histiocytic, endocrinologic or basically reactive factors. ${ }^{1}$ Females are affected 8-10 times more frequently than males. ${ }^{1}$ It has been suggested that the more common occurrence of congenital epulis in females implies a hormonal mechanism of development. However, a hormonal stimulus was not confirmed because no oestrogen or progesterone receptors have been found on the tumour to support such a hypothesis.

Congenital epulis presents as a mass protruding through the oral cavity of a newborn child. It arises from the alveolar mucosa and occurs more frequently in the maxilla, mainly on its frontal region at the site of unerupted deciduous canines. Congenital epulis usually manifests as a single lesion; however, multiple tumours have been reported in $10 \%$ of cases. ${ }^{3}$ The tumour consists of a smooth or tuberous ovoid mass connected by a broad or narrow pendulum to the alveolar mucosa. The appearance of congenital epulis may be lobulated. The lesion has a pink or reddish colour and its size varies from several millimeters to a few centimeters in diameter. The consistency of congenital epulis is firm and elastic. Congenital epulis is not usually associated with any other developmental anomalies of the teeth or other oral tissues.

Large lesions may interfere with respiration, feeding or adequate closure of the mouth. Extremely large congenital epulis can cause complications even before birth. Obstruction of the infant's mouth may result in impaired swallowing of amniotic fluid, resulting in polyhydramnios. ${ }^{4}$

\section{CASE PRESENTATION}

A 1-day-old Caucasian female born by normal vaginal delivery was recommended for diagnosis and treatment at the Paediatric Dentistry Department of the Faculty Hospital in Pilsen, Czech Republic due to the presence of a mass in the alveolar ridge of the upper jaw. The infant was born on the 36th week of gestation. The newborn's mother was healthy; this was her second pregnancy and delivery. Pregnancy and delivery were without complications. The birth weight of the infant was $3200 \mathrm{~g}$, length was $50 \mathrm{~cm}$ and Apgar score was $10-10-10$.

Clinical examination of the newborn revealed a solid ovoid mass of approximately $12 \times 10 \times 6 \mathrm{~mm}$ protruding from the infant's oral cavity (figure 1). The tumour was localised in the left part of the maxillary canine region. Its surface was smooth and covered with reddish mucosa. The

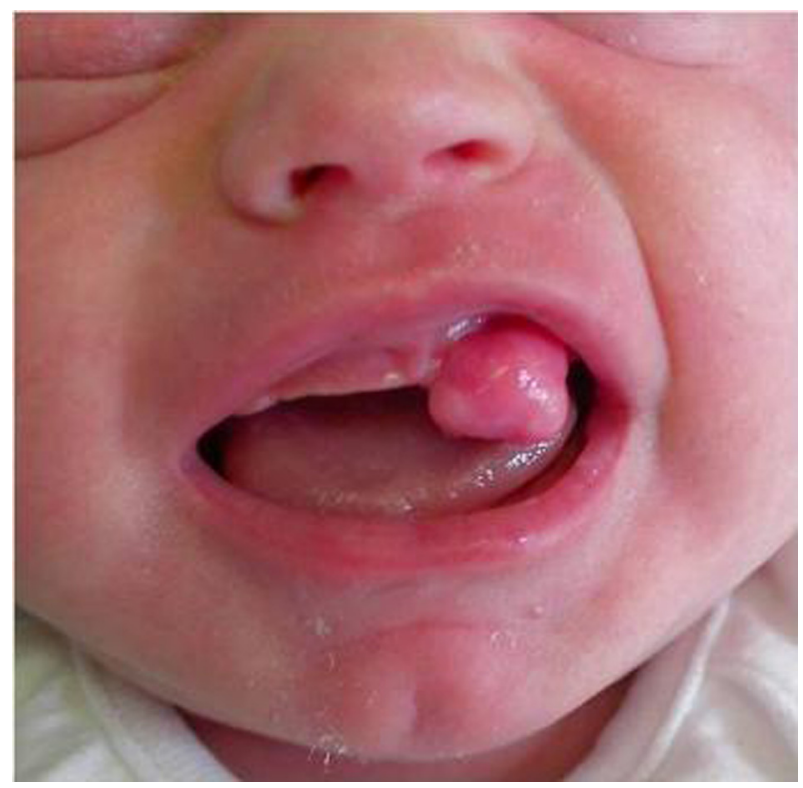

Figure 1 Solid ovoid mass protruding from the infant's oral cavity. 
consistency of the lesion was elastic. The tumour was connected by a broad pendulum to the mucosa of the alveolar ridge, which resulted in insufficient mouth closure. The lesion did not interfere with respiration or breastfeeding. No other abnormal finding was noted in the infant's oral cavity. At the first visit, the infant's mother did not agree with recommended surgical treatment of the lesion.

The second visit of the infant to our department was 13 days later. Problems with breastfeeding had arisen during the last few days. The lesion in the oral cavity was larger, and its surface was tuberous. A clinical diagnosis of congenital epulis was suspected based on the presence of typical clinical symptoms. The clinical findings and feeding problem in the newborn indicated the need for surgical intervention and the infant's mother signed informed consent with surgical treatment.

\section{INVESTIGATIONS}

The histological examination confirmed the clinical diagnosis of congenital epulis. The lesion was a well-circumscribed nodule with a smooth surface. Microscopic sections were studied after routine paraffin embedding and basic H\&E staining. Microscopically, the lesion was covered by stratified squamous epithelium from the gingival mucosa with intact basement membrane. The cut surface was homogeneous and pale. The whole tumour was composed of nearly uniform round-to-polygonal cells with eosinophilic, finely granular cytoplasm, round nuclei and distinct cell membranes. The minimal, richly vascularised stroma was composed of fibrous connective tissue (figure 2). No mitoses or necroses were visible in the lesion. Histochemical examination revealed diastase-resistant PAS (periodic acid Schiff) positivity. The tumour cells were immunohistochemically positive for vimentin but negative for $\mathrm{S}-100$ protein, inhibin, smooth muscle actin, myogenin, calponin, desmin, CD68, CD31, CD34 and keratins.

\section{DIFFERENTIAL DIAGNOSIS}

The differential diagnosis of a mass in the fetal or neonatal oral cavity should include congenital malformations, such as encephalocoele, dermoid cysts, teratomas as well as benign and malignant tumours. ${ }^{1-3}$ In terms of tumours,

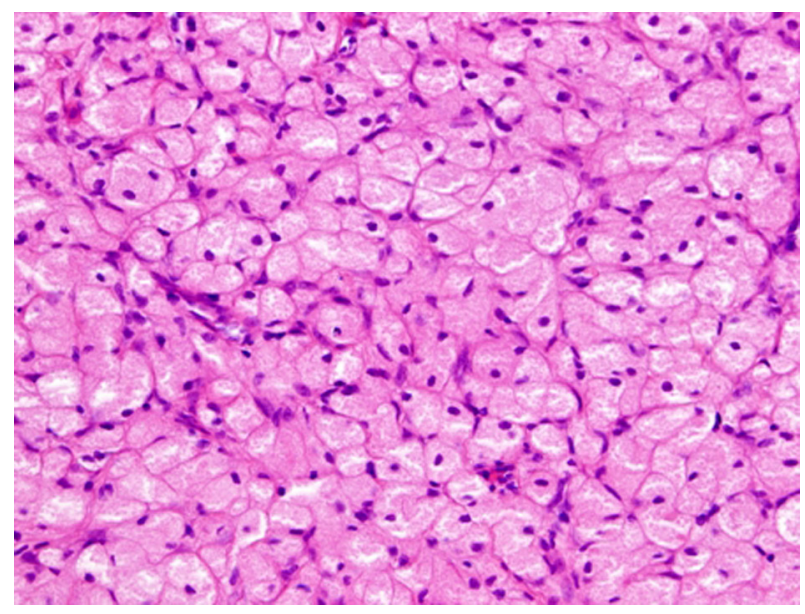

Figure 2 High-power view showing round-to-polygonal tumour cells with eosinophilic granular cytoplasm, with round nuclei and distinct cell membranes. haemangioma, fibroma, granuloma, embryonal rhabdomyosarcoma, malignant granular cell myoblastoma, alveolar rhabdomyosarcoma, chondrosarcoma and osteosarcoma and schwannoma should be considered. The differential diagnosis of congenital epulis should be based on the predominance of female patients, tumour location on the anterior maxillary region, presence at birth, and absence of growth potential.

Congenital epulis is quite often confused with the congenital granular cell tumour. ${ }^{5}$ Despite the histological similarities, these entities have considerably different clinical, histochemical, epidemiological and pathological features, which justify their classification as distinct lesion. Congenital granular cell tumour is rare condition in newborns and is also rare in alveolar ridge. The most common site for this tumour is tongue or buccal mucosa. Histologically congenital epulis and granular cell tumour contain large cells with eosinophilic granular cytoplasm, ${ }^{5}$ but the congenital epulis is covered with a normal gingival epithelium with atrophy of the rete ridges whereas granular cell tumour has pseudoepitheliomatous hyperplasia on its surface. Immunohistochemical examination with antiserum to $\mathrm{S}-100$ protein is positive only for the granular cell tumour. ${ }^{16}$

\section{TREATMENT}

Under local anaesthesia (articain hydrochloridum), the tumour was completely excised with electrocautery. Operative haemorrhage was minimal, and therefore the excision was left without suture to heal per secundam intentionem. The excised tumour was sent for histopathological examination. The infant was able to breastfeed 10 min after surgical treatment.

\section{OUTCOME AND FOLLOW-UP}

Postsurgical follow-up was without complications; the site of excision healed completely within a few days. At 2 weeks after surgery, the infant was reviewed in the Paediatric Dentistry Department. A small bowl defect was evident at the excision site. The same finding was present during follow-up a month after surgery (figure 3).

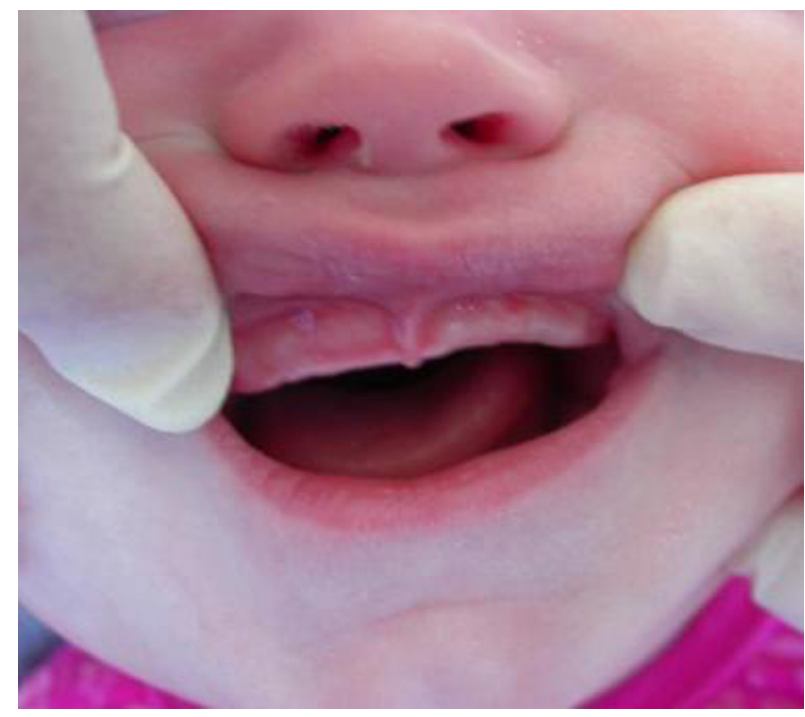

Figure 3 Follow-up a month after surgery. 


\section{DISCUSSION}

Congenital epulis can be diagnosed prenatally or postnatally. The diagnosis of large congenital epulis can be made before birth during routine obstetrical sonography. ${ }^{4}$ Typical observation is echogenic identification of a well-circumscribed, non-septate mass with Doppler findings inconsistent with haemangioma. Prenatal diagnosis of congenital epulis is rare because it develops slowly during the third trimester of pregnancy. MRI can be used for prenatal and postnatal diagnosis of congenital epulis, but this examination is nonspecific. ${ }^{1}$ In general, it revealed a soft-tissue mass without involvement of the tooth germs. A clinical diagnosis of congenital epulis is usually not difficult due to the predictable appearance and characteristic occurrence in the maxillary alveolar ridge in female neonates. In rare cases mandibular region and the tongue can also be involved?

Surgical excision is the only possible treatment for congenital epulis, ${ }^{1} 3$ although spontaneous regression has been reported. ${ }^{2}$ Surgical treatment should not be radical because it is necessary to minimise the danger of damaging alveolar bone and developing teeth. In literature ${ }^{2}$ no recurrence has been reported, despite the incomplete resection. There are also no reports of malignant changes or serious disturbances of alveolar or tooth development. ${ }^{9}$
Acknowledgements Many thanks to Dr T Maňáková, pathologist at Faculty Hospital in Pilsen, Czech Republic, for cooperation during histopathological examination of the child.

Competing interests None.

Patient consent Obtained.

\section{REFERENCES}

1. Lapid 0, Shaco-Levy R, Krieger Y, et al. Congenital epulis. Pediatrics 2001:107:E22.

2. Ritwik P, Brannon RB, Musselman RJ. Spontaneous regression of congenital epulis: a case report and review of the literature. J Med Case Reports 2010;4:331.

3. Olson JL, Marcus JR, Zuker RM. Congenital epulis. J Craniofac Surg 2005; 16:161-4

4. Nakata M, Anno K, Matsumori LT, et al. Prenatal diagnosis of congenital epulis: a case report. Ultrasound Obstet Gynecol 2002;20:627-9.

5. Adeyemi BF, Oluwasola A0, Adisa A0. Congenital epulis. Indian J Dent Res 2010;21:292-4.

6. Steffen J, Harper D. Congenital Epulis. Consultant For Pediatricians 2011:10:167-8

7. Kayıran SM, Buyukunal C, Ince U, et al. Congenital epulis of the tongue: A case report and review of the literature. JRSM Short Rep 2011;2:62.

8. Diniz MB, Giro Elisa MA, Zuanon Angela CC, et al. Congenital epulis: a rare benign tumor in the newborn. J Indian Soc Pedod Prev Dent 2010;28:230-3.

9. Sunderland R, Sunderland EP, Smith CJ. Hypoplasia following congenital epulis. Br Dent J 1984;157:353.

\section{Learning points}

- Congenital epulis is a rare intraoral tumour in oral cavity of newborns.

- The differential diagnosis for an infant with the congenital epulis would include congenital malformations, such as encephalocoele, dermoid cysts, teratomas as well as benign and malignant tumours. In terms of tumours, congenital granular cell tumour, haemangioma, fibroma, granuloma, embryonal rhabdomyosarcoma, malignant granular cell myoblastoma, alveolar rhabdomyosarcoma, chondrosarcoma and osteosarcoma and schwannoma should be considered.

- The surgical excision is the only possible treatment of congenital epulis.

- Malignant changes of congenital epulis are not reported.

This pdf has been created automatically from the final edited text and images.

Copyright 2012 BMJ Publishing Group. All rights reserved. For permission to reuse any of this content visit http://group.bmi.com/group/rights-licensing/permissions.

BMJ Case Report Fellows may re-use this article for personal use and teaching without any further permission.

Please cite this article as follows (you will need to access the article online to obtain the date of publication).

Merglová V, Mukensnabl P, Andrle P. Congenital epulis. BMJ Case Reports 2012;10.1136/bcr.01.2012.5483, Published XXX

Become a Fellow of BMJ Case Reports today and you can:

- Submit as many cases as you like

- Enjoy fast sympathetic peer review and rapid publication of accepted articles

- Access all the published articles

- Re-use any of the published material for personal use and teaching without further permission

For information on Institutional Fellowships contact consortiasales@bmjgroup.com

Visit casereports.bmj.com for more articles like this and to become a Fellow

Keep up to date with all published cases by signing up for an alert (all we need is your email address) http://casereports.bmj.com/cgi/alerts/etoc 